\title{
Methylobacterium cerastii sp. nov., isolated from the leaf surface of Cerastium holosteoides
}

Correspondence

S. Wellner

stefanie.a.wellner@umwelt.unigiessen.de

\author{
S. Wellner, N. Lodders and P. Kämpfer
} Institut für Angewandte Mikrobiologie, Justus-Liebig-Universität Giessen, D-35392 Giessen,
Germany

Two Gram-stain-negative, non-endospore-forming, rod-like strains, designated $\mathrm{C}_{15}{ }^{\top}$ and $\mathrm{C} 44$, were isolated from the phyllosphere of Cerastium holosteoides and were studied in detail in order to assess their taxonomic position. 16S rRNA gene sequence analysis allocated both isolates clearly to the genus Methylobacterium. Both strains showed the highest 16S rRNA gene sequence similarity to Methylobacterium marchantiae $\mathrm{JT}^{\top}{ }^{\top}(97.5 \%)$ and Methylobacterium jeotgali S2R03- $9^{\top}(97.4 \%)$. The fatty acid profiles contained major amounts of $\mathrm{C}_{16: 0,0}, \mathrm{C}_{18: 1} \omega 7 \mathrm{c}$ and $\mathrm{C}_{16: 1} \omega 7 \mathrm{c} /$ iso- $\mathrm{C}_{15: 0} 2-\mathrm{OH}$ (summed feature 3 ), which supported the grouping of the isolates in the genus Methylobacterium. Physiological/biochemical characterization and

DNA-DNA hybridizations with the type strains of the most closely related species allowed a clear phenotypic and genotypic differentiation of the strains. For this reason, we propose for strain $\mathrm{C}_{15}{ }^{\top}$ (=DSM $23679^{\top}=$ CCUG $60040^{\top}=$ CCM $7788^{\top}$ ) a novel species with the name Methylobacterium cerastii sp. nov. Strain C44 (=DSM $23675=$ CCM 7789) is an additional strain of $M$. cerastii.
The genus Methylobacterium was initially proposed by Patt et al. (1976) with the type species Methylobacterium organophilum and is classified in the class Alphaproteobacteria. Species of the genus Methylobacterium are strictly aerobic, facultatively methylotrophic, Gram-negative, rod-shaped bacteria that can grow on single-carbon compounds such as formate, formaldehyde and methanol as the sole source of carbon and energy, as well as on a wide range of multicarbon growth substrates (Green, 2006).

Methylobacterium strains are sometimes called pink-pigmented facultative methylotrophs (PPFMs) due to their characteristic pink pigmentation. These pigments are carotenoids, mainly xanthophylls (Urakami et al., 1993; Konovalova et al., 2007). However, it should be noted that two type strains of the genus, Methylobacterium nodulans ORS $2060^{\mathrm{T}}$ and Methylobacterium jeotgali S2R03-9 ${ }^{\mathrm{T}}$, are not pigmented.

At the time of writing, the genus Methylobacterium comprised 35 recognized species: M. adhaesivum (Gallego et al., 2006), M. aerolatum (Weon et al., 2008), M. aminovorans (Urakami et al., 1993), M. aquaticum (Gallego et al., 2005a), M. brachiatum (Kato et al., 2008), M. chloromethanicum (McDonald et al., 2001), M. dichloromethanicum (Doronina et al., 2000),

Abbreviation: pNP, p-nitrophenyl.

The GenBank/EMBL/DDBJ accession numbers for the 16S rRNA gene sequences of strains $C 15^{\top}$ and $\mathrm{C} 44$ are FR733885 and FR733886, respectively. The accession numbers for the $m x a F$ gene sequences of strains $C 15^{\top}$ and $\mathrm{C} 44$ are FR847841 and FR847842, respectively.

A supplementary figure is available with the online version of this paper.
M. extorquens (Bousfield \& Green, 1985), M. fujisawaense (Green et al., 1988), M. gregans (Kato et al., 2008), M. hispanicum (Gallego et al., 2005a), M. iners (Weon et al., 2008), M. isbiliense (Gallego et al., 2005c), M. jeotgali (Aslam et al., 2007), M. komagatae (Kato et al., 2008), M. lusitanum (Doronina et al., 2002), M. marchantiae (Schauer et al., 2011), M. mesophilicum (Green \& Bousfield, 1983), M. nodulans (Jourand et al., 2004), M. organophilum (Patt et al., 1976), M. oryzae (Madhaiyan et al., 2007), M. persicinum (Kato et al., 2008), M. phyllosphaerae (Madhaiyan et al., 2009), M. platani (Kang et al., 2007), M. podarium (Anesti et al., 2004), M. populi (Van Aken et al., 2004), M. radiotolerans (Green \& Bousfield, 1983), M. rhodesianum (Green et al., 1988), M. rhodinum (Green \& Bousfield, 1983), M. salsuginis (Wang et al., 2007), M. suomiense (Doronina et al., 2002), M. tardum (Kato et al., 2008), M. thiocyanatum (Wood et al., 1998), M. variabile (Gallego et al., 2005b) and M. zatmanii (Green et al., 1988). In addition, the species 'Methylobacterium goesingense' was proposed by Idris et al. (2006) but the name has not been validly published.

Members of the genus Methylobacterium are ubiquitous in nature and can be found in such diverse habitats as soil, freshwater, sewage, in the human mouth and on feet (Doronina et al., 2002; Kato et al., 2008; Anesti et al., 2004; Anesti et al., 2005). They are known particularly for their close association with plants (Corpe \& Rheem 1989; Holland \& Polacco, 1994; Lidstrom \& Chistoserdova, 2002; Sy et al., 2005). They have been isolated for example from stem tissue of rice (Madhaiyan et al., 2007), leaf tissue of rice (Madhaiyan et al., 2009) and leaf samples of plane 
Table 1. Differential phenotypic characteristics of the novel isolates and related species of the genus Methylobacterium.

Taxa: 1, strain $\mathrm{C} 15^{\mathrm{T}}$; 2, strain C44; 3, M. organophilum LMG 6083 ${ }^{\mathrm{T}}$; 4, M. jeotgali S2R03-9 ${ }^{\mathrm{T}}$; 5, M. phyllosphaerae DSM 19779 ${ }^{\mathrm{T}}$; 6, M. oryzae DSM $18207^{\mathrm{T}}$; 7, M. fujisawaense DSM 5686 ${ }^{\mathrm{T}}$; 8 , M. marchantiae JT1 ${ }^{\mathrm{T}}$. +, Positive; - , negative; $(+)$, weak; v, variable results. Data were obtained comparatively in this study. Results in brackets are from: 3, Patt et al. (1976, 1974); 4, Aslam et al. (2007); 5, Madhaiyan et al. (2009); 6, Madhaiyan et al. (2007); 7, Green et al. (1988); 8, Schauer et al. (2011). All strains were positive for hydrolysis of bis-p-nitrophenyl (bis-pNP) phosphate* and Lalanine $p$-nitroanilide $(\mathrm{pNA})^{*} \dagger$ and negative for hydrolysis of $\mathrm{pNP} \beta$-D-xylopyranoside ${ }^{*}$. All strains were negative for acid production from $\mathrm{D}$ trehalose $^{\star}$ and assimilation of maltitol* ${ }^{\star}$ D-mannitol ${ }^{\star}$ and L-leucine ${ }^{\star}$.

\begin{tabular}{|c|c|c|c|c|c|c|c|c|}
\hline Characteristic & 1 & 2 & 3 & 4 & 5 & 6 & 7 & 8 \\
\hline \multicolumn{9}{|l|}{ Acid produced from: } \\
\hline D-Glucose $e^{\star} / \ddagger$ & $-1-$ & $-1-$ & $+1-$ & $-1-$ & $-1-$ & $-1-$ & $-1-$ & $-1-$ \\
\hline L-Arabinose $e^{\star}$ & - & + & + & - & + & + & + & - \\
\hline D-Xylose $/ \ddagger$ & $-1+$ & $-1+$ & $+1+$ & $-1+$ & $+/+$ & $+/+$ & $+/+$ & $-1+$ \\
\hline D-Mannose ${ }^{*}$ & - & - & + & - & - & - & - & - \\
\hline Rhamnose $\ddagger$ & + & + & + & + & + & + & + & + \\
\hline \multicolumn{9}{|c|}{ Assimilation as sole carbon source } \\
\hline Methane§ & - & - & $-[+]$ & $-[-]$ & {$[-]$} & {$[-]$} & {$[-]$} & - \\
\hline Formamidell & + & - & - & + & + & - & $(+)$ & + \\
\hline Formaldehydell & - & - & - & $(+)[+]$ & {$[-]$} & {$[-]$} & - & - \\
\hline Methylaminell & - & - & $-[-]$ & {$[+]$} & {$[(+)]$} & {$[-]$} & {$[-]$} & - \\
\hline Formatell & - & - & - & - & $(+)[+]$ & {$[+]$} & - & - \\
\hline L-Glutamate $\dagger$ & $(+)$ & + & + & + & $+[+]$ & $+[+]$ & + & $+[+]$ \\
\hline Tartrate $\dagger$ & - & - & - & - & $-[-]$ & $-[-]$ & $-[\mathrm{V}]$ & $-[+]$ \\
\hline Ethanol $\dagger$ & - & - & $+[+]$ & + & $+[(+)]$ & $-[(+)]$ & $(+)[\mathrm{V}]$ & + \\
\hline$N$-Acetyl D-galactosamine ${ }^{*}$ & - & - & + & - & - & - & - & - \\
\hline$N$-Acetyl D-glucosamine ${ }^{\star}$ & + & - & - & - & - & - & - & - \\
\hline L-Arabinose $e^{*}$ & $-/(+)$ & $-1+$ & $-1-$ & $-1-$ & $-/+[+]$ & $+/+[+]$ & $+/+[+]$ & $-/-[-]$ \\
\hline $\mathrm{D}-$ Fructose $^{\star} / \dagger$ & $-1-$ & $-1-$ & $+1+$ & $-/-[-]$ & $-/-[+]$ & $-/-[-]$ & $+/+[\mathrm{V}]$ & $+1+[+]$ \\
\hline D-Galactose ${ }^{\star}$ & - & - & $-[+]$ & - & + & - & - & - \\
\hline D-Glucose $e^{\star} \dagger$ & $-1-$ & $-1-$ & $+/+[+]$ & $-/-[-]$ & $-/+[(+)]$ & $-/-[-]$ & $-/+[+]$ & $-/-[-]$ \\
\hline D-Ribose* & - & + & $-[-]$ & - & - & + & + & - \\
\hline Sucrose $e^{\star}$ & - & - & - & - & + & - & - & - \\
\hline Trehalose $e^{\star}$ & - & - & + & - & - & - & - & - \\
\hline D-Xylose $e^{\star} / \dagger$ & $-1-$ & $-1-$ & $+1-$ & $-/-[+]$ & $+/+[+]$ & $-/+[-]$ & $-/+[+]$ & $-1-[-]$ \\
\hline D-Sorbitol ${ }^{*}$ & - & + & - & - & - & - & - & - \\
\hline Putrescine $e^{\star}$ & + & - & - & - & - & - & - & - \\
\hline Sodium acetate $\mathrm{e}^{\star} / \dagger$ & $-1-$ & $-1-$ & $+/+[+]$ & $+/-[+]$ & $-/+[(+)]$ & $-/+[-]$ & $-/-[+]$ & $+1+[+]$ \\
\hline Propionate $^{\star}$ & - & - & + & + & - & - & - & + \\
\hline cis-Aconitate ${ }^{\star}$ & - & + & - & - & - & - & - & - \\
\hline trans-Aconitate ${ }^{*}$ & - & + & - & - & - & - & - & - \\
\hline Adipate & - & + & - & - & + & + & + & - \\
\hline Azelate ${ }^{\star}$ & - & + & - & - & + & + & + & - \\
\hline Citrate $^{\star} / \uparrow$ & $-1-$ & $+1-$ & $-1-$ & $-/-[-]$ & $-/-[+]$ & $-/-[-]$ & $-/-[+]$ & $-/-[(+)]$ \\
\hline Fumarate ${ }^{\star}$ & - & + & + & + & - & - & - & + \\
\hline Glutarate $^{*}$ & - & + & + & - & - & - & + & - \\
\hline DL-3-Hydroxybutyrate & - & + & + & + & - & + & + & + \\
\hline Itaconate $^{*}$ & - & - & + & - & $(+)$ & - & - & - \\
\hline DL-Lactate ${ }^{*}$ & - & + & + & + & + & - & - & + \\
\hline L-Malate* & - & + & $+[+]$ & + & - & - & - & + \\
\hline Mesaconate & - & + & - & - & - & - & - & - \\
\hline Oxoglutarate & + & + & - & - & - & - & - & + \\
\hline Pyruvate $^{*}$ & - & + & + & + & - & - & - & + \\
\hline Suberate* & - & + & $(+)$ & - & + & + & + & - \\
\hline L-Alanine $e^{*}$ & - & - & - & - & + & - & - & - \\
\hline$\beta$-Alanine ${ }^{*}$ & - & - & $(+)$ & - & - & - & - & - \\
\hline L-Aspartate ${ }^{*}$ & - & - & + & + & + & - & - & + \\
\hline L-Histidine ${ }^{\star}$ & - & + & - & - & - & - & - & - \\
\hline L-Phenylalanine $e^{\star}$ & - & + & - & - & - & - & - & - \\
\hline
\end{tabular}


Table 1. cont.

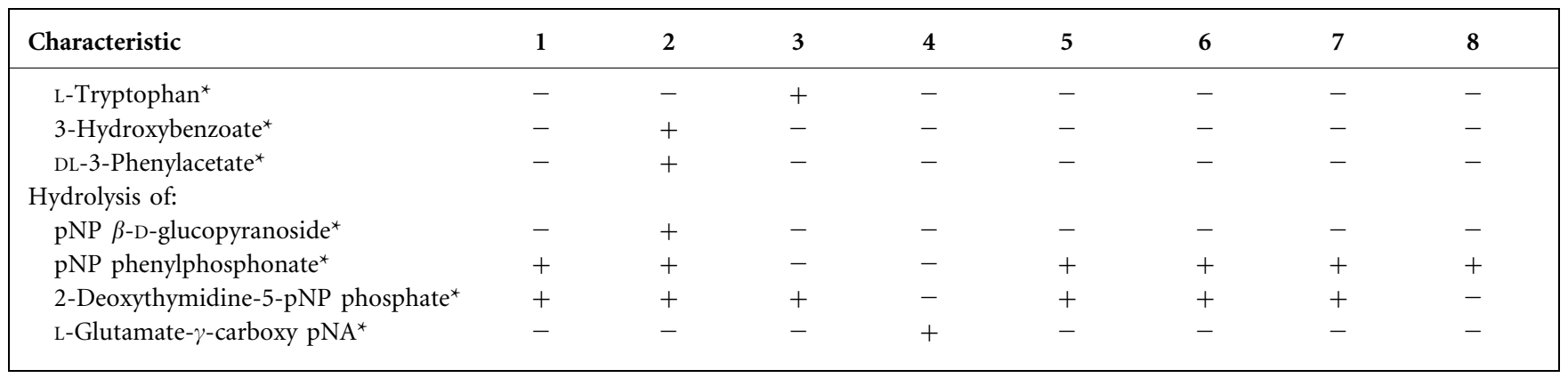

${ }^{\star}$ Result from F-panel according to Kämpfer et al. (1991).

†Growth in M125 supplemented with $0.5 \%$ substrate.

$\ddagger$ Result from Micronaut E.

§Growth in M125 where methane was provided as head space gas in the proportion 50:50 methane/air.

IIGrowth in M125 supplemented with $0.1 \%$ substrate.

(Kang et al., 2007), internal poplar tissue (Van Aken et al., 2004) and root nodules (Jourand et al., 2004). Associations of members of the genus Methylobacterium with plants range from epiphytic to endophytic and symbiotic relations (Sy et al., 2001; Koenig et al., 2002; Pirttilä et al., 2000; Idris et al., 2006). A recent culture-independent analysis showed that the genus Methylobacterium is one of the predominant genera in the phyllosphere, together with the genera Sphingomonas and Pseudomonas (Delmotte et al., 2009). Methylobacteria are able to utilize the methanol emitted from plants and, in turn, produce plant-growth-promoting substances such as indole-3-acetic acid (IAA), cytokinins or vitamins (Ivanova et al., 2000; Ivanova et al., 2001; Ivanova et al., 2006; Koenig et al., 2002; Trotsenko et al., 2001).

Strains $\mathrm{C} 15^{\mathrm{T}}$ and $\mathrm{C} 44$ were isolated from the leaf surface of Cerastium holosteoides plants, collected in the Hainich-Dün region, Germany, a region that is systematically studied in the framework of a comprehensive biodiversity program (Fischer et al., 2010).

Bacteria were removed from the leaf surface with potassium phosphate buffer $\left(6.75 \mathrm{~g} \mathrm{KH}_{2} \mathrm{PO}_{4}, 8.75 \mathrm{~g} \mathrm{~K}_{2} \mathrm{HPO}_{4}\right.$ per litre) and mechanical treatment (Stomacher 80 Biomaster; Seward Laboratory Systems). Serial dilutions were plated on mineral salt medium supplemented with $0.5 \%$ methanol (M125, according to DSMZ) and incubated at $25{ }^{\circ} \mathrm{C}$ for 14 days. Pink-pigmented colonies with different morphology were isolated.

Cellular morphology and motility were determined microscopically (fluorescence microscope Axiophot2; Zeiss) using exponentially grown M125 broth cultures. Gram-staining was performed as described by Gerhardt et al. (1994). Both strains were aerobic, Gram-stain-negative, rod-shaped, non-motile and formed pink- to red-pigmented colonies. Production of the enzymes catalase and oxidase was tested positive with $3 \% \mathrm{H}_{2} \mathrm{O}_{2}$ and $1 \%$ tetramethyl-p-phenylenediamine dihydrochloride, respectively, according to Gerhardt et al. (1994).

Growth on different media was monitored over 21 days at $28{ }^{\circ} \mathrm{C}$. The tested media were: Caso (Carl Roth), GP (M85, according to DSMZ), K7 (M1199, according to DSMZ), LB (Sigma-Aldrich), M65 (according to DSMZ), marine (Becton Dickinson), NA (Becton Dickinson), nutrient (Oxoid), PCA (5 g casein peptone, $2.5 \mathrm{~g}$ yeast extract, $1 \mathrm{~g}$ glucose, $9 \mathrm{~g}$ agar per litre, $\mathrm{pH}$ 7.0), PYE (3 g yeast extract, $3 \mathrm{~g}$ peptone, $15 \mathrm{~g}$ agar per litre, $\mathrm{pH} 7.2$ ), PYG (20 g glucose, $10 \mathrm{~g}$ yeast extract, $10 \mathrm{~g}$ bacto peptone, $15 \mathrm{~g}$ agar per litre), R2A (Oxoid), TGE (M1207, according to DSMZ) and TS medium (Becton Dickinson).

For various physiological tests, bacteria were grown in medium M125. Growth at various temperatures $(4,10,16$, $20,25,28,36$ and $45{ }^{\circ} \mathrm{C}$ ), different initial methanol concentrations $(0.1,0.3,0.5,0.7,1.0,1.5$ and $2.0 \%)$ and different initial $\mathrm{pH}(4.0,5.0,6.0,7.0,7.2,8.0$ and 10.0) was monitored after 3 and 14 days. Salt $(\mathrm{NaCl})$-tolerance was assessed in M125 broth supplemented with 0, 0.5, 1.0, 2.0, 3.0 and $4.0 \%(\mathrm{w} / \mathrm{v}) \mathrm{NaCl}$ over a period of 14 days. Assimilation of acetate, L-arabinose, citrate, ethanol, Dfructose, D-glucose, L-glutamate, tartrate and D-xylose was monitored in M125 broth supplemented with $0.5 \%$ substrate. Growth on different $\mathrm{C}_{1}$ compounds was tested in M125 broth supplemented with $0.1 \%$ formaldehyde, formate, formamide or methylamine, respectively, instead of methanol. Assimilation of methane was carried out in M125 broth where methane was provided as head space gas in the proportions 50:50 methane/air according to Green (2006). Hydrolysis of starch was tested with iodine solution after growth on modified Bennett agar (Williams et al., 1989). Indole formation, hydrolysis of adonitol, citrate, glucose, inositol, malonate, n-nitrophenyl galactopyranoside, rhamnose, sucrose and xylose as well as production of the enzymes arginine dihydrolase, lysine decarboxylase, ornithine decarboxylase, tryptophan deaminase and urease were determined with the micronaut $\mathrm{E}$ test plate (Merlin Diagnostika) following the manufacturer's instructions. Comparative physiological characterization of the isolates and the most closely related species of the genus Methylobacterium were carried out according to Kämpfer et al. (1991). 
Like other members of the genus, both strains grew on methanol. Strain $\mathrm{C} 15^{\mathrm{T}}$ grew on formamide, but not on formaldehyde, formate or methylamine. Strain C44 did not grow on $\mathrm{C}_{1}$ compounds other than methanol. The positive control, which consisted of M125 broth containing $0.1 \%$ methanol, showed growth for all tested strains. Neither strain grew on methane. M. organophilum LMG $6083^{\mathrm{T}}$ also did not grow on methane although it was described to utilize methane (Patt et al., 1974; Patt et al., 1976). However, Green \& Bousfield (1983) previously reported that $M$. organophilum lost its ability to utilize methane. Other physiological features are summarized in the species description. The strains differed from their closest relatives in several carbon-source utilization features (Table 1). In contrast to M. marchantiae $\mathrm{JT}^{\mathrm{T}}$ and M. jeotgali S2R03-9 ${ }^{\mathrm{T}}$, neither strain utilized $\mathrm{L}$-aspartate, ethanol or propionate as sole carbon source but hydrolysed p-nitrophenyl (pNP) phosphate.

For the extraction of pigments, bacteria were grown in R2A broth (Lab M). Bacterial suspension was centrifuged for $5 \mathrm{~min}$ at 14000 r.p.m., washed twice with $1 \times \mathrm{PBS}$ and dissolved in $80 \%(\mathrm{v} / \mathrm{v})$ methanol. After sonification for $7 \mathrm{~min}$, the bacterial suspension was incubated at $-20{ }^{\circ} \mathrm{C}$ for $24 \mathrm{~h}$ in the dark. The resulting suspension was centrifuged for $5 \mathrm{~min}$ at 14000 r.p.m. to remove the insoluble cell debris. Thereafter, the supernatant was measured at wavelengths from 300 to $900 \mathrm{~nm}$ in an Infinite 200 Pro microplate reader (Tecan) against $80 \%$ methanol as reference. Since carotenoids are known to be esterified by long chain fatty acids, an additional saponification procedure was applied to a subsample of the extracted pigments; $0.4 \mathrm{ml} 0.01 \mathrm{M} \mathrm{NaOH}$ was added to $1 \mathrm{ml}$ extract and the mixture was incubated at room temperature for $8 \mathrm{~h}$ in the dark (Stepnowski et al., 2004). For both isolates, the pigments extracted with methanol showed absorption peaks at 490 and $520 \mathrm{~nm}$, respectively, and a weak peak at $460 \mathrm{~nm}$. These absorption maxima have also been reported by Schauer et al. (2011) and Urakami et al. (1993) indicating that strains $\mathrm{C}^{2} 5^{\mathrm{T}}$ and $\mathrm{C} 44$ contain the same carotenoids as previously described Methylobacterium strains. In addition, a peak at $314 \mathrm{~nm}$ was detected for isolate $\mathrm{C} 5^{\mathrm{T}}$. Furthermore, a peak at $360 \mathrm{~nm}$ was detected in methanolic cell extracts which was also present in the non-pigmented control $M$. jeotgali

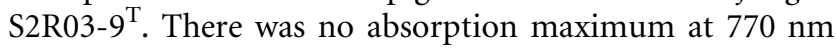
detected, indicating that bacteriochlorophyll $a$ is not present in strains $\mathrm{C} 15^{\mathrm{T}}$ and C44.

Genomic DNA was extracted using a commercially available kit (GenElute Plant Genomic DNA miniprep kit; Sigma-Aldrich) according to the manufacturer's instructions.

Nearly full-length 16S rRNA gene sequences (1353/ $1350 \mathrm{nt})$ were amplified with the universal eubacterial 16S rRNA gene primers 27F and 1492R (Lane, 1991). PCR amplification was performed with a thermocycler in a total volume of $50 \mu \mathrm{l}$. The reaction mixture contained $32 \mu \mathrm{l}$
RNase/DNase free water, $5 \mu \mathrm{l} 10 \times$ Taq Buffer (containing $\mathrm{KCl}), 4 \mu \mathrm{l} 25 \mathrm{nM} \mathrm{MgCl} 2,5 \mu \mathrm{l} 2 \mathrm{mM}$ dNTPs, $0.9 \mu \mathrm{l}$ each

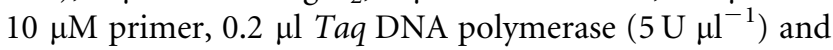
$1 \mu \mathrm{l}$ genomic DNA. PCRs consisted of 33 cycles (45 s at $94{ }^{\circ} \mathrm{C}, 45 \mathrm{~s}$ annealing at $57.3{ }^{\circ} \mathrm{C}$, and $2 \mathrm{~min}$ at $72{ }^{\circ} \mathrm{C}$ ) with an initial denaturation of $3 \mathrm{~min}$ at $95{ }^{\circ} \mathrm{C}$ and a final elongation step of $15 \mathrm{~min}$ at $72{ }^{\circ} \mathrm{C}$.

A partial sequence (471 nt) of the $m x a F$ gene was amplified using primers 1003f and 1561r (McDonald et al., 1995). PCR amplification was performed in a total volume of $50 \mu \mathrm{l}$; the reaction mixture contained $31.8 \mu \mathrm{l}$ RNase/DNase free water, $5 \mu \mathrm{l} 10 \times$ Taq Buffer (containing $\mathrm{KCl}$ ), $6 \mu \mathrm{l}$ $25 \mathrm{nM} \mathrm{MgCl}_{2}, 4 \mu \mathrm{l} 2 \mathrm{mM}$ dNTPs, $1 \mu \mathrm{l}$ each $10 \mu \mathrm{M}$ primer, $0.2 \mu \mathrm{l} \mathrm{Taq}$ DNA polymerase $\left(5 \mathrm{U}^{-1}\right)$ and $1 \mu \mathrm{l}$ genomic DNA. PCRs consisted of 30 cycles $\left(60 \mathrm{~s}\right.$ at $92{ }^{\circ} \mathrm{C}, 60 \mathrm{~s}$ annealing at $55{ }^{\circ} \mathrm{C}$, and $60 \mathrm{~s}$ at $72{ }^{\circ} \mathrm{C}$ ) with an initial denaturation of $3 \mathrm{~min}$ at $95{ }^{\circ} \mathrm{C}$ and a final elongation step of $5 \mathrm{~min}$ at $72{ }^{\circ} \mathrm{C}$.

PCR products were purified with the QIAquick PCR purification system (Qiagen), sequenced with the primers listed above and aligned by using the software packages MEGA4 (Tamura et al., 2007) and ClUSTAL w (Thompson et al., 1994). Phylogenetic trees were reconstructed with the neighbour-joining (Saitou \& Nei, 1987) and maximumparsimony methods using the software package MEGA4 (Tamura et al., 2007). A bootstrap confidence analysis was performed on 1000 replicates to determine the reliability of the tree topology obtained (Felsenstein, 1985). Additionally, multiple alignment of the data and analysis of the sequences were performed using the software package ARB (version December 2007; Ludwig et al., 2004) with the corresponding SILVA SSURef 100 database (release August 2009; Pruesse et al., 2007). Tree reconstruction using the maximum-likelihood method with fastDNAml (Olsen et al., 1994) was performed with the ARB software package (see Supplementary Fig. S1, available in IJSEM Online). Comparative 16S rRNA gene sequence analysis indicated that both strains were located within the genus Methylobacterium. Sequence similarity calculations and phylogenetic analysis revealed that strains $\mathrm{C} 15^{\mathrm{T}}$ and C44 were closely related to $M$. marchantiae $\mathrm{JT}^{\mathrm{T}}{ }^{\mathrm{T}}(97.5 \%)$ and $M$. jeotgali S2R03- $9^{\mathrm{T}}(97.4 \%)$. A neighbour-joining tree is shown in Fig. 1. Phylogenetic analyses with maximum-likelihood (Supplementary Fig. S1) and maximum-parsimony (results not shown) methods showed slightly different results. The sequence similarity between strains $\mathrm{C} 15^{\mathrm{T}}$ and $\mathrm{C} 44$ was $100 \%$. A neighbour-joining tree based on the mxaF gene is given in Fig. 2.

DNA-DNA hybridization studies were performed according to Ziemke et al. (1998) with a hybridization temperature of $73.4{ }^{\circ} \mathrm{C}$ after isolation of genomic DNA according to the method of Pitcher et al. (1989). DNADNA hybridization experiments resulted in DNA-DNA similarity values of $20.4 \%$ (reciprocal $34.6 \%$ ) and $11.1 \%$ (reciprocal $28.0 \%$ ) in pairing $M$. jeotgali S2R03- $-9^{\mathrm{T}}$ with $\mathrm{C} 15^{\mathrm{T}}$ and C44, respectively, and in DNA-DNA similarity 


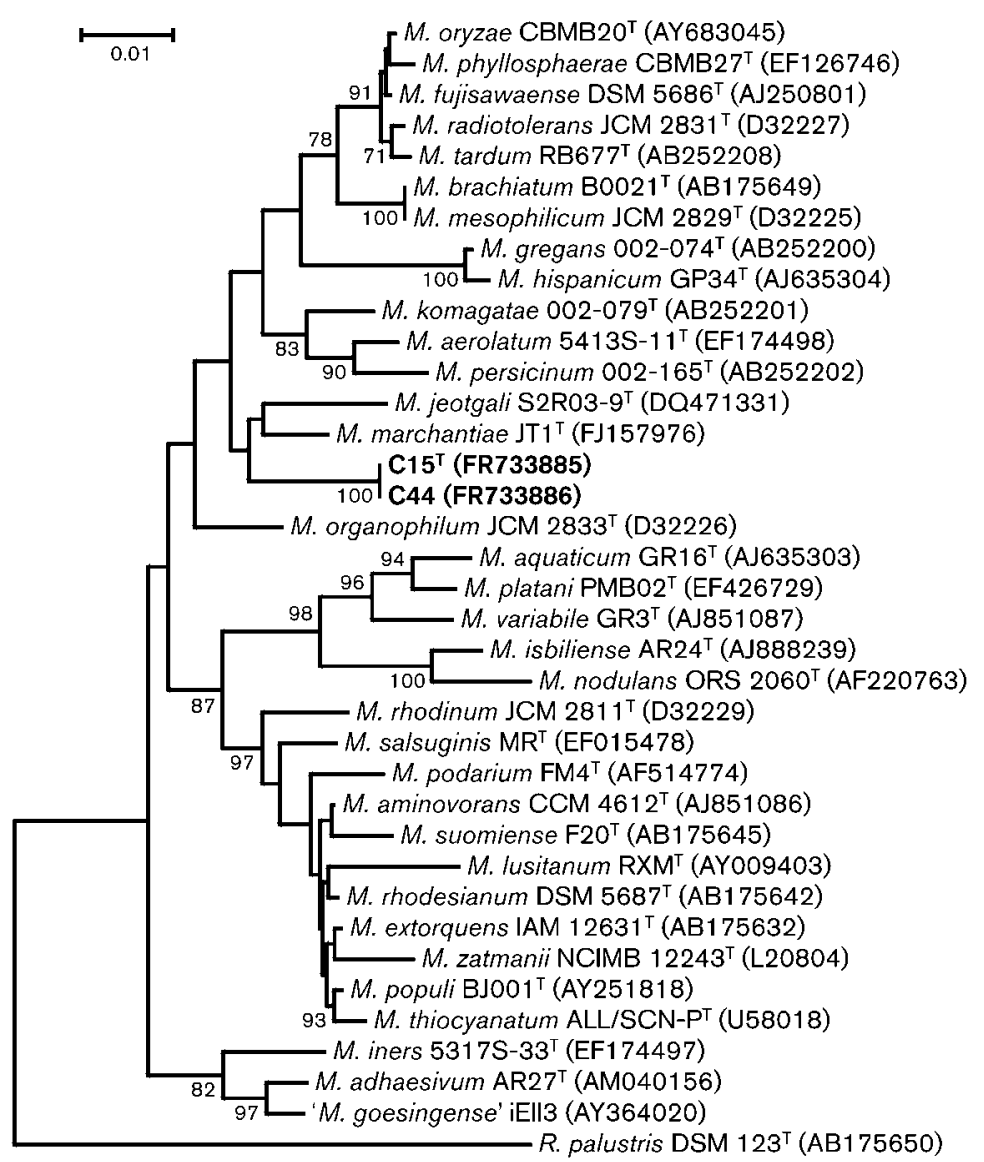

Fig. 1. Phylogenetic tree reconstruction from a comparative analysis based on 36 individual 16S rRNA gene sequences (1353 nt), available from the European Molecular Biology Laboratory database (accession numbers in parentheses), which shows the relationship between strains $\mathrm{C} 15^{\top}$ and $\mathrm{C} 44$ and members of related taxa. Evolutionary history was inferred using the neighbour-joining method. Bootstrap values (expressed as percentages of 1000 replications) higher than $70 \%$ are shown at nodes. The sequence of Rhodopseudomonas palustris DSM $123^{\top}$ was used as an outgroup. Bar, $1 \%$ sequence dissimilarity.

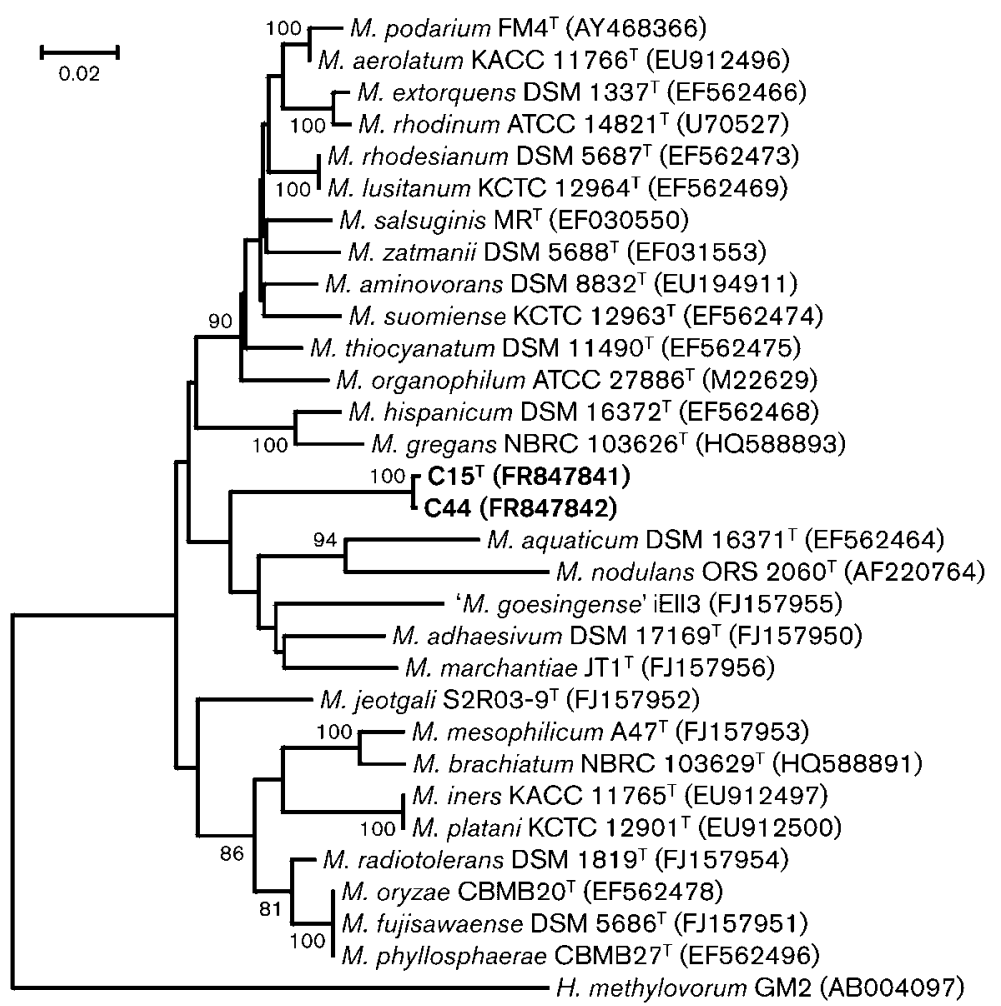

Fig. 2. Phylogenetic tree reconstruction from a comparative analysis based on 27 partial $m x a F$ gene sequences (519 nt), available from the European Molecular Biology Laboratory database (accession numbers in parentheses), which shows the relationship between strains $\mathrm{C} 15^{\top}$ and $\mathrm{C} 44$ and members of related taxa. Evolutionary history was inferred using the neighbour-joining method. Bootstrap values (expressed as percentages of 1000 replications) higher than $70 \%$ are shown at nodes. The sequence of Hyphomicrobium methylovorum GM2 was used as an outgroup. Bar, $2 \%$ sequence dissimilarity. 
values of $30.5 \%$ (reciprocal $12.3 \%$ ) and $5.5 \%$ (reciprocal $12.3 \%$ ) in pairing M. marchantiae $\mathrm{JT}^{\mathrm{T}}$ with $\mathrm{C} 5^{\mathrm{T}}$ and C44, respectively. Pairing strain $\mathrm{C}^{1} 5^{\mathrm{T}}$ with strain $\mathrm{C} 44$ showed DNA-DNA similarity values of $75.8 \%$ (reciprocal $69.5 \%)$.

Whole-cell fatty acid analysis was carried out using the MIDI protocol as previously described (Kämpfer \& Kroppenstedt, 1996), except that cells were grown on M125 at $25{ }^{\circ} \mathrm{C}$ prior to fatty acid extraction according to the MIDI protocol. The samples were investigated using a model 5898A microbial identification system (Microbiol ID) and the Microbial Identification System standard software (Microbial ID; version TSBA 4.1). The fatty acid profiles of both strains were very similar to that of closely related species of the genus Methylobacterium (Table 2), consisting mainly of $\mathrm{C}_{16: 0}, \mathrm{C}_{18: 1} \omega 7 c$ and $\mathrm{C}_{16: 1} \omega 7 c /$ iso$\mathrm{C}_{15: 0}$ 2-OH (summed feature 3 ).

On the basis of the phenotypic differences observed, the results of the DNA-DNA hybridization studies and the differences in 16S rRNA gene sequences, we propose a novel species of the genus Methylobacterium with the name Methylobacterium cerastii sp. nov. and with strain $\mathrm{C} 15^{\mathrm{T}}$ as the type strain. As a result of recent work, including DNADNA hybridization, we also propose that strain C44 be considered as a strain of $M$. cerastii sp. nov.

\section{Description of Methylobacterium cerastii sp. nov.}

Methylobacterium cerastii (ce.ras'ti.i. N.L. n. Cerastium, a scientific genus name; N.L. gen. n. cerastii of Cerastium, isolated from Cerastium holosteoides).

Aerobic, Gram-stain-negative, rod-shaped and immotile. Cells of strain $\mathrm{C} 15^{\mathrm{T}}$ are approximately $0.8-1.1 \times 1.6-5.4 \mu \mathrm{m}$ in size and cells of strain C44 are approximately $0.7-$ $1.1 \times 2.0-4.9 \mu \mathrm{m}$ in size. Slow-growing with a growth rate $(\mu)$ of approximately $0.05-0.06 \mathrm{~h}^{-1}$. Grows on R2A, nutrient, PYG, PYE, LB, M65, PCA, K7, NA and TGE media and on M125 supplemented with 0.1-2.0\% methanol $(\mathrm{v} / \mathrm{v})$; no growth detected on TS, GP, caso or marine media. Colonies are pinkish coloured, shiny, smooth, circular, with entire margins and a diameter of $1.0-2.0 \mathrm{~mm}$ on M125 agar after 7 days of incubation at $25{ }^{\circ} \mathrm{C}$. Pigments have absorption maxima in $80 \%(\mathrm{v} / \mathrm{v})$ methanol at 360,490 and $520 \mathrm{~nm}$, respectively, and a weak peak at $460 \mathrm{~nm}$. Pigments of strain $\mathrm{C}^{2} 5^{\mathrm{T}}$ have an additional absorption maximum in $80 \%(\mathrm{v} / \mathrm{v})$ methanol at $314 \mathrm{~nm}$. Produce catalase and oxidase. Strain $\mathrm{C} 15^{\mathrm{T}}$ grows at $10-28{ }^{\circ} \mathrm{C}$ (optimum $20^{\circ} \mathrm{C}$ ) and $\mathrm{pH}$ 4.0-6.0 (optimum 5.0-6.0). Strain $\mathrm{C} 44$ grows at $16-28{ }^{\circ} \mathrm{C}$ (optimum $20-28{ }^{\circ} \mathrm{C}$ ) and pH 5.0-7.0 (optimum 6.0). No growth at temperatures below $4{ }^{\circ} \mathrm{C}$ or above $36{ }^{\circ} \mathrm{C}$ as well as $\mathrm{pH}$ greater than 7.2. Growth in medium supplemented with $0.5 \% \mathrm{NaCl}$ or higher salt concentrations is not observed. Do not hydrolyse starch but do hydrolyse L-alanine pNP, pNP phenylphosphate, bis-pNP phosphate and pNP phosphate; strain C44 additionally hydrolyses pNP $\beta$-D-glucopyranoside. Indole test is negative and Voges-Proskauer test is positive. Urease is produced, but arginine dihydrolase, lysine decarboxylase, ornithine decarboxylase and tryptophan deaminase are not. $\mathrm{H}_{2} \mathrm{~S}$ is not produced.

Results of tests for carbon-source utilization are summarized in Table 1. Strain C44 can utilize cis-aconitate, transaconitate, adipate, azelate, fumarate, L-glutamate, glutarate, L-histidine, 3-hydroxybenzoate, DL-3-hydroxybutyrate, DLlactate, L-malate, mesaconate, oxoglutarate, DL-3-phenylacetate, L-phenylalanine, pyruvate, D-ribose, D-sorbitol and suberate as sole carbon source; results are not consistent for citrate and L-arabinose utilization. Strain $\mathrm{C} 15^{\mathrm{T}}$ can utilize $\mathrm{N}$-acetyl-D-glucosamine, L-glutamate, oxoglutarate and putrescine as sole carbon source; results for L-arabinose

Table 2. Major fatty acid compositions (\%) of type strains of species of the genus Methylobacterium that are closely related to the novel strains investigated

Taxa: 1, strain $\mathrm{C} 15^{\mathrm{T}} ; 2$, strain C44; 3, M. organophilum LMG $6083^{\mathrm{T}} ; 4$, M. jeotgali S2R03-9 ${ }^{\mathrm{T}} ; 5$, M. phyllosphaerae DSM 19779 ${ }^{\mathrm{T}}$; 6 , M. oryzae DSM $18207^{\mathrm{T}} ; 7$, M. fujisawaense DSM $5686^{\mathrm{T}} ; 8$, M. marchantiae $\mathrm{JT}^{\mathrm{T}}$. All data were obtained comparatively in this study.

\begin{tabular}{|c|c|c|c|c|c|c|c|c|}
\hline Fatty acid & 1 & 2 & 3 & 4 & 5 & 6 & 7 & 8 \\
\hline anteiso- $\mathrm{C}_{15: 0}$ & 1.7 & & & & & & & \\
\hline $\mathrm{C}_{16: 0}$ & 3.9 & 3.5 & 3.2 & 3.4 & 5.0 & 5.0 & 4.8 & 6.2 \\
\hline $\mathrm{C}_{18: 0}$ & 0.9 & 2.7 & 4.6 & 3.4 & 3.2 & 5.4 & 2.7 & 1.5 \\
\hline $\mathrm{C}_{18: 1} \omega 7 c^{\star}$ & 81.3 & 76.6 & 89.5 & 89.6 & 87.2 & 85.1 & 86.5 & 74.8 \\
\hline Summed feature $3 \dagger$ & 8.4 & 17.3 & & & 2.4 & & 2.7 & 15.1 \\
\hline Summed feature $2 \dagger$ & 1.8 & & 2.8 & 3.7 & & & & 2.5 \\
\hline Unknown $14.263 末$ & & & & & 2.2 & 4.6 & 3.3 & \\
\hline Unknown $14.959 \ddagger$ & 2.1 & & & & & & & \\
\hline
\end{tabular}

${ }^{\star}$ For unsaturated fatty acids, the position of the double bond is located by counting from the methyl $(\omega)$ end of the carbon chain. $\dagger$ Summed features are groups of two or three fatty acids that cannot be separated by GLC with the MIDI system. Summed feature 2 contained one or more of the fatty acids iso- $\mathrm{C}_{16: 1} \mathrm{I}$ and $\mathrm{C}_{14: 0} 3-\mathrm{OH}$. Summed feature 3 contained one or more of the fatty acids $\mathrm{C}_{16: 1} \omega 7 c$ and iso- $\mathrm{C}_{15: 0} 2-\mathrm{OH}$. $¥$ The unknown fatty acids have no name listed in the peak library file of the MIDI system and therefore cannot be identified. 
are variable. Strain $\mathrm{C} 15^{\mathrm{T}}$ grows on formamide, but not on formaldehyde, formate or methylamine. Strain C44 does not grow on $\mathrm{C}_{1}$ compounds other than methanol. Does not grow on methane. Major fatty acids are $\mathrm{C}_{16: 0}, \mathrm{C}_{18: 1} \omega 7 c$ and summed feature $3 \quad\left(\mathrm{C}_{16: 1} \omega 7 c /\right.$ iso- $\left.\mathrm{C}_{15: 0} \quad 2-\mathrm{OH}\right)$. Additionally, strain $\mathrm{C}^{2} 5^{\mathrm{T}}$ contains small amounts of $\mathrm{C}_{15: 0}$. The type strain is $\mathrm{C}^{2} 5^{\mathrm{T}}\left(=\mathrm{DSM} 23679^{\mathrm{T}}=\mathrm{CCUG} 60040^{\mathrm{T}}\right.$ $=\mathrm{CCM} 7788^{\mathrm{T}}$ ), isolated from the leaf surface of Cerastium holosteoides.

\section{Acknowledgements}

We are grateful to Gundula Will and Maria Sowinsky for excellent technical assistance. We thank Dr Jean Euzéby for his nomenclatural advice. The studies were supported by the DFG Priority Program 1374 'Infrastructure-Biodiversity-Exploratories', grant number Ka 875/6-1 to P. K., which is gratefully acknowledged.

\section{References}

Anesti, V., Vohra, J., Goonetilleka, S., McDonald, I. R., Sträubler, B., Stackebrandt, E., Kelly, D. P. \& Wood, A. P. (2004). Molecular detection and isolation of facultatively methylotrophic bacteria, including Methylobacterium podarium sp. nov., from the human foot microflora. Environ Microbiol 6, 820-830.

Anesti, V., McDonald, I. R., Ramaswamy, M., Wade, W. G., Kelly, D. P. \& Wood, A. P. (2005). Isolation and molecular detection of methylotrophic bacteria occurring in the human mouth. Environ Microbiol 7, 1227-1238.

Aslam, Z., Lee, C. S., Kim, K.-H., Im, W.-T., Ten, L. N. \& Lee, S.-T. (2007). Methylobacterium jeotgali sp. nov., a non-pigmented, facultatively methylotrophic bacterium isolated from jeotgal, a traditional Korean fermented seafood. Int J Syst Evol Microbiol 57, 566-571.

Bousfield, I. J. \& Green, P. N. (1985). Reclassification of bacteria of the genus Protomonas Urakami and Komagata 1984 in the genus Methylobacterium (Patt, Cole, and Hanson) emend. Green and Bousfield 1983. Int J Syst Bacteriol 35, 209.

Corpe, W. A. \& Rheem, S. (1989). Ecology of the methylotrophic bacteria on living leaf surfaces. FEMS Microbiol Ecol 62, 243-249.

Delmotte, N., Knief, C., Chaffron, S., Innerebner, G., Roschitzki, B., Schlapbach, R., von Mering, C. \& Vorholt, J. A. (2009). Community proteogenomics reveals insights into the physiology of phyllosphere bacteria. Proc Natl Acad Sci U S A 106, 16428-16433.

Doronina, N. V., Trotsenko, Y. A., Tourova, T. P., Kuznetsov, B. B. \& Leisinger, T. (2000). Methylopila helvetica sp. nov. and Methylobacterium dichloromethanicum sp. nov.-novel aerobic facultatively methylotrophic bacteria utilizing dichloromethane. Syst Appl Microbiol 23, 210-218.

Doronina, N. V., Trotsenko, Y. A., Kuznetsov, B. B., Tourova, T. P. \& Salkinoja-Salonen, M. S. (2002). Methylobacterium suomiense sp. nov. and Methylobacterium lusitanum sp. nov., aerobic, pinkpigmented, facultatively methylotrophic bacteria. Int J Syst Evol Microbiol 52, 773-776.

Felsenstein, J. (1985). Confidence limits on phylogenies: an approach using the bootstrap. Evolution 39, 783-791.

Fischer, M., Bossdorf, O., Gockel, S., Hänsel, F., Hemp, A., Hessenmöller, D., Korte, G., Nieschulze, J., Pfeiffer, S. \& other authors (2010). Implementing large-scale and long-term functional biodiversity research: The Biodiversity Exploratories. Basic Appl Ecol 11, 473-485.
Gallego, V., García, M. T. \& Ventosa, A. (2005a). Methylobacterium hispanicum sp. nov. and Methylobacterium aquaticum sp. nov., isolated from drinking water. Int J Syst Evol Microbiol 55, 281-287.

Gallego, V., Garcia, M. T. \& Ventosa, A. (2005b). Methylobacterium variabile sp. nov., a methylotrophic bacterium isolated from an aquatic environment. Int J Syst Evol Microbiol 55, 1429-1433.

Gallego, V., Garcia, M. T. \& Ventosa, A. (2005c). Methylobacterium isbiliense sp. nov., isolated from the drinking water system of Sevilla, Spain. Int J Syst Evol Microbiol 55, 2333-2337.

Gallego, V., García, M. T. \& Ventosa, A. (2006). Methylobacterium adhaesivum sp. nov., a methylotrophic bacterium isolated from drinking water. Int J Syst Evol Microbiol 56, 339-342.

Gerhardt, P., Murray, R. G. E., Wood, W. A. \& Krieg, N. R. (editors) (1994). Methods for General and Molecular Bacteriology. Washington, DC: American Society for Microbiology.

Green, P. N. (2006). Methylobacterium. In The Prokaryotes. A Handbook on the Biology of Bacteria, 3rd edn, vol. 5, pp. 257-265. Edited by M. Dworkin, S. Falkow, E. Rosenberg, K. H. Schleifer \& E. Stackebrandt. New York: Springer.

Green, P. N. \& Bousfield, I. J. (1983). Emendation of Methylobacterium (Patt, Cole, and Hanson 1976); Methylobacterium rhodinum (Heumann 1962) comb. nov. corrig.; Methylobacterium radiotolerans (Ito \& Iizuka 1971) comb. nov., corrig.; and Methylobacterium mesophilicum (Austin \& Goodfellow 1979) comb. nov. Int J Syst Bacteriol 33, 875-877.

Green, P. N., Bousfield, I. J. \& Hood, D. (1988). Three new Methylobacterium species: M. rhodesianum sp. nov., M. zatmanii sp. nov., and M. fujisawaense sp. nov. Int J Syst Bacteriol 38, 124-127.

Holland, M. A. \& Polacco, J. C. (1994). PPFMs and other covert contaminants: is there more to plant physiology than just plant? Annu Rev Plant Physiol Plant Mol Biol 45, 197-209.

Idris, R. A., Kuffner, M., Bodrossy, L., Puschenreiter, M., Monchy, S., Wenzel, W. W. \& Sessitsch, A. (2006). Characterization of Ni-tolerant methylobacteria associated with the hyperaccumulating plant Thlaspi goesingense and description of Methylobacterium goesingense sp. nov. Syst Appl Microbiol 29, 634-644.

Ivanova, E. G., Doronina, N. V., Shepeliakovskaia, A. O., Laman, A. G., Brovko, F. A. \& Trotsenko, Yu. A. (2000). Facultative and obligate aerobic methylobacteria synthesize cytokinins. Microbiology (English translation of Mikrobiologiia) 69, 646-651.

Ivanova, E. G., Doronina, N. V. \& Trotsenko, Yu. A. (2001). Aerobic methylobacteria are capable of synthesizing auxins. Microbiology (English translation of Mikrobiologiia) 70, 392-397.

Ivanova, E. G., Fedorov, D. N., Doronina, N. V. \& Trotsenko, Yu. A. (2006). Production of vitamin B12 in aerobic methylotrophic bacteria. Microbiology (English translation of Mikrobiologiia) 75, 494-496.

Jourand, P., Giraud, E., Béna, G., Sy, A., Willems, A., Gillis, M., Dreyfus, B. \& de Lajudie, P. (2004). Methylobacterium nodulans sp. nov., for a group of aerobic, facultatively methylotrophic, legume root-nodule-forming and nitrogen-fixing bacteria. Int J Syst Evol Microbiol 54, 2269-2273.

Kämpfer, P. \& Kroppenstedt, R. M. (1996). Numerical analysis of fatty acid patterns of coryneform bacteria and related taxa. Can $\mathrm{J}$ Microbiol 42, 989-1005.

Kämpfer, P., Steiof, M. \& Dott, W. (1991). Microbiological characterization of a fuel-oil contaminated site including numerical identification of heterotrophic water and soil bacteria. Microb Ecol 21, 227-251.

Kang, Y.-S., Kim, J., Shin, H.-D., Nam, Y.-D., Bae, J.-W., Jeon, C. O. \& Park, W. (2007). Methylobacterium platani sp. nov., isolated from a 
leaf of the tree Platanus orientalis. Int J Syst Evol Microbiol 57, 2849 2853.

Kato, Y., Asahara, M., Goto, K., Kasai, H. \& Yokota, A. (2008). Methylobacterium persicinum sp. nov., Methylobacterium komagatae sp. nov., Methylobacterium brachiatum sp. nov., Methylobacterium tardum sp. nov. and Methylobacterium gregans sp. nov., isolated from freshwater. Int J Syst Evol Microbiol 58, 1134-1141.

Koenig, R. L., Morris, R. O. \& Polacco, J. C. (2002). tRNA is the source of low-level trans-zeatin production in Methylobacterium spp. J Bacteriol 184, 1832-1842.

Konovalova, H. M., Shylin, S. O. \& Rokytko, P. V. (2007). [Characteristics of carotinoids of methylotrophic bacteria of Methylobacterium genus]. Mikrobiol Z 69, 35-41 (in Ukrainian).

Lane, D. J. (1991). 16S/23S rRNA sequencing nucleic acid techniques in bacterial systematics. In Nucleic Acid Techniques in Bacterial Systematics, pp. 115-175. Edited by E. Stackebrandt \& M. Goodfellow. Chichester: Wiley.

Lidstrom, M. E. \& Chistoserdova, L. (2002). Plants in the pink: cytokinin production by methylobacterium. J Bacteriol 184, 1818.

Ludwig, W., Strunk, O., Westram, R., Richter, L., Meier, H., Yadhukumar, Buchner, A., Lai, T., Steppi, S. \& other authors (2004). ARB: a software environment for sequence data. Nucleic Acids Res 32, 1363-1371.

Madhaiyan, M., Kim, B. Y., Poonguzhali, S., Kwon, S. W., Song, M. H., Ryu, J. H., Go, S. J., Koo, B. S. \& Sa, T. M. (2007). Methylobacterium oryzae sp. nov., an aerobic, pink-pigmented, facultatively methylotrophic, 1-aminocyclopropane-1-carboxylate deaminase-producing bacterium isolated from rice. Int J Syst Evol Microbiol 57, 326-331.

Madhaiyan, M., Poonguzhali, S., Kwon, S. W. \& Sa, T. M. (2009). Methylobacterium phyllosphaerae sp. nov., a pink-pigmented, facultative methylotroph from the phyllosphere of rice. Int J Syst Evol Microbiol 59, 22-27.

McDonald, I. R., Kenna, E. M. \& Murrell, J. C. (1995). Detection of methanotrophic bacteria in environmental samples with the PCR. Appl Environ Microbiol 61, 116-121.

McDonald, I. R., Doronina, N. V., Trotsenko, Y. A., McAnulla, C. \& Murrell, J. C. (2001). Hyphomicrobium chloromethanicum sp. nov. and Methylobacterium chloromethanicum sp. nov., chloromethane-utilizing bacteria isolated from a polluted environment. Int J Syst Evol Microbiol 51, 119-122.

Olsen, G. J., Matsuda, H., Hagstrom, R. \& Overbeek, R. (1994). fastDNAmL: a tool for construction of phylogenetic trees of DNA sequences using maximum likelihood. Comput Appl Biosci 10, 41-48.

Patt, T. E., Cole, G. C., Bland, J. \& Hanson, R. S. (1974). Isolation and characterization of bacteria that grow on methane and organic compounds as sole sources of carbon and energy. J Bacteriol 120, 955964.

Patt, T. E., Cole, G. C. \& Hanson, R. S. (1976). Methylobacterium, a new genus of facultatively methylotrophic bacteria. Int J Syst Bacteriol 26, 226-229.

Pirttilä, A. M., Laukkanen, H., Pospiech, H., Myllylä, R. \& Hohtola, A. (2000). Detection of intracellular bacteria in the buds of Scotch pine (Pinus sylvestris L.) by in situ hybridization. Appl Environ Microbiol 66, 3073-3077.

Pitcher, D. G., Saunders, N. A. \& Owen, R. J. (1989). Rapid extraction of bacterial genomic DNA with guanidium thiocyanate. Lett Appl Microbiol 8, 151-156.

Pruesse, E., Quast, C., Knittel, K., Fuchs, B. M., Ludwig, W., Peplies, J. \& Glöckner, F. O. (2007). SILVA: a comprehensive online resource for quality checked and aligned ribosomal RNA sequence data compatible with ARB. Nucleic Acids Res 35, 7188-7196.

Saitou, N. \& Nei, M. (1987). The neighbor-joining method: a new method for reconstructing phylogenetic trees. Mol Biol Evol 4, 406425.

Schauer, S., Kämpfer, P., Wellner, S., Spröer, C. \& Kutschera, U. (2011). Methylobacterium marchantiae sp. nov., a pink-pigmented, facultatively methylotrophic bacterium isolated from the thallus of a liverwort. Int J Syst Evol Microbiol 61, 870-876.

Stepnowski, P., Blotevogel, K.-H. \& Jastorff, B. (2004). Extraction of carotenoid produced during methanol waste biodegradation. Int Biodeterior Biodegradation 53, 127-132.

Sy, A., Giraud, E., Jourand, P., Garcia, N., Willems, A., de Lajudie, P., Prin, Y., Neyra, M., Gillis, M. \& other authors (2001). Methylotrophic Methylobacterium bacteria nodulate and fix nitrogen in symbiosis with legumes. J Bacteriol 183, 214-220.

Sy, A., Timmers, A. C. J., Knief, C. \& Vorholt, J. A. (2005). Methylotrophic metabolism is advantageous for Methylobacterium extorquens during colonization of Medicago truncatula under competitive conditions. Appl Environ Microbiol 71, 7245-7252.

Tamura, K., Dudley, J., Nei, M. \& Kumar, S. (2007). MEGA4: molecular evolutionary genetics analysis (MEGA) software version 4.0. Mol Biol Evol 24, 1596-1599.

Thompson, J. D., Higgins, D. G. \& Gibson, T. J. (1994). CLUSTAL W: improving the sensitivity of progressive multiple sequence alignment through sequence weighting, position-specific gap penalties and weight matrix choice. Nucleic Acids Res 22, 4673-4680.

Trotsenko, Y. A., Ivanova, E. G. \& Doronina, N. V. (2001). Aerobic methylotrophic bacteria as phytosymbionts. Microbiology 70, 623632.

Urakami, T., Araki, H., Suzuki, K. \& Komagata, K. (1993). Further studies of the genus Methylobacterium and description of Methylobacterium aminovorans sp. nov. Int J Syst Bacteriol 43, 504513.

Van Aken, B., Peres, C. M., Doty, S. L., Yoon, J. M. \& Schnoor, J. L. (2004). Methylobacterium populi sp. nov., a novel aerobic, pinkpigmented, facultatively methylotrophic, methane-utilizing bacterium isolated from poplar trees (Populus deltoides $\times$ nigra DN34). Int J Syst Evol Microbiol 54, 1191-1196.

Wang, X., Sahr, F., Xue, T. \& Sun, B. (2007). Methylobacterium salsuginis sp. nov., isolated from seawater. Int J Syst Evol Microbiol 57, 1699-1703.

Weon, H.-Y., Kim, B.-Y., Joa, J.-H., Son, J.-A., Song, M.-H., Kwon, S.-W., Go, S.-J. \& Yoon, S.-H. (2008). Methylobacterium iners sp. nov. and Methylobacterium aerolatum sp. nov., isolated from air samples in Korea. Int J Syst Evol Microbiol 58, 93-96.

Williams, S. T., Goodfellow, M. \& Alderson, G. (1989). Genus Streptomyces Waksman and Henrici 1943, 339 ${ }^{\mathrm{AL}}$. In Bergey's Manual of Systematic Bacteriology, vol. 4, pp. 2452-2492. Edited by S. T. Williams, M. E. Sharpe \& J. G. Holt. Baltimore: Williams \& Wilkins.

Wood, A. P., Kelly, D. P., McDonald, I. R., Jordan, S. L., Morgan, T. D., Khan, S., Murrell, J. C. \& Borodina, E. (1998). A novel pinkpigmented facultative methylotroph, Methylobacterium thiocyanatum sp. nov., capable of growth on thiocyanate or cyanate as sole nitrogen sources. Arch Microbiol 169, 148-158.

Ziemke, F., Höfle, M. G., Lalucat, J. \& Rosselló-Mora, R. (1998). Reclassification of Shewanella putrefaciens Owen's genomic group II as Shewanella baltica sp. nov. Int J Syst Bacteriol 48, 179-186. 